\title{
PENINGKATAN MUTU PEMBELAJARAN BERBASIS ANEKA SUMBER BELAJAR DI MTSN SUMBER BUNGUR PAMEKASAN
}

\author{
Ali Wafa \\ STIDKIS Al-Mardliyyah Pamekasan \\ Email: awafa9851@gmail.com
}

\begin{abstract}
Abstrak:
Guru merupakan salah satu faktor yang menentukan keberhasilan proses pembelajaran. Proses pembelajaran harus ditunjang oleh fasilitas pembelajaran atau sumber belajar yang memadai serta didukung oleh kemampuan dan keterampilan guru dalam melaksanakan pembelajaran. Penelitian ini menggunakan pendekatan kualitatif deskriptif karena endekatan ini cocok digunakan untuk memperoleh pemahaman mendalam tentang fenomena sosial. Metode yang digunakan dalam pengumpulan data adalah observasi dan wawancara. Tujuan penelitian ini yaitu untuk mengetahui (1) peningkatan mutu pembelajaran berbasis aneka sumber; (2) perncanaan pembelajaran berbasis aneka sumber belajar; (3) dampak peningkatan mutu pembelajaran. Hasil penelitiannya (1) dalam meningkatkan mutu pembelajaran sekolah melengkapi fasilitas atau sumber belajar yang memadai dan melakukan pembinaan guru-guru secara terus-menerus; (2) dalam perencanaan guru mengacu pada kurikulum khususnya silabus sebagai acuan utama dalam menyusun perencanaan pembelajaran dan disesuaikan dengan kondisi sekolah. Di dalamnya memuat materi, media, pendekatan, metode, dan penilaian; (3) pada tahun 2016-2017 banyak meraih prestasi baik tingkat Kabupaten, Madura, Jawa Timur, Nasional dan bahkan Internasional.
\end{abstract}

Kata Kunci: Mutu Pembelajaran, Sumber Belajar

\begin{abstract}
:
The teacher is one factors that determine the success of learning process. The learning process should be supported by learning facility or learning resources that are adequate and supported by teachers ability and skills in learning implemention. This research used a descriptive approach because it is suitable for obtaining a
\end{abstract}


deep understanding of the social phenomenon. The methode was used in data collection are observation and interview.The purpose of this study is to know: (1) the improvement of leaning resources based learning; (2) the planning of learning resources various learning resources; (3) the impact of learning gualities improvement. The results of his research (1) in improving the quality of school learning complementary facilities or learning resources adequate and continuous mentoring the teachers; (2) in teacher planing refers to curriculum especially syllabus as the main reference in preparing lesson planning and adapted to school conditions. Inside determines the material, media, approaches, methods, and assessments; (3) at 2016-2017 a lot of achievement both district level, Madura, East Java, National and even international.

Keywords: Quality of Learning and Learning Resources

\section{Pendahuluan}

Pendidikan selama ini dipandang sebagai sarana membentuk dan membimbing peserta didik guna mengantarkan mereka ke arah pencapaian cita-cita tertentu dan perubahan perilaku yang lebih baik. Pendidikan juga dipercaya sebagai proses perubahan perilaku ke arah yang lebih baik dari sebelumnya. Namun, sampai saat ini pendidikan yang dipercaya sebagai sarana perubahan tersebut belum sepenuhnya mampu merubah perilaku peserta didik ke arah yang lebih baik, bahkan yang terjadi justru sebalilknya. Tak sedikit peserta didik yang hanya manguasi ranah pengetahuan (kognitif) saja, sedangkan ranah yang lain seperti ranah afektif terutama ranah psikomotoriknya sangat rendah. Sehingga tidak mampu bersaing dalam dunia kerja.

Hal ini menjadi sorotan negatif terhadap dunia pendidikan atau sekolah karena di pandang belum mampu mencetak output lulusan sebagaimana yang diharapkan. Pendidikan yang diharapkan selama ini adalah pendidikan yang menghasilkan lulusan yang mampu mengusai ketiga ranah di atas, yakni kognitif, ranah afektif, dan psikomotorik. Banyaknya perlaku yang amoral, seperti tauran, minum-minuman keras dan lain-lain merupakan salah satu kegagalan dalam menguasai ranah afektif bagi peserta didik. Di samping itu, ketidak mampuan dalam bersaing atau berkompetisi dalam dunia kerja merupakan salah satu kegagalan bagi peserta didik dalam menguasai ranah psikomotoriknya. Hal 
tersebut juga kegagalan bagi guru dalam mentransfer nilai-nilai afektif dan psikomotorik ke dalam proses pembelajaran.

Di samping itu, selama ini dalam pembelajaran yang dibawa guru masih cenderung bersifat konvesional. Artinya guru sering menentukan satu buku sebagai satu-satunya sumber belajar. Hal ini mengakibatkan potensi yang dimiliki peserta didik tidak akan berkembang. Padahal salah satu tujuan pendidikan adalah ingin mengembangkan potensi peserta didiki. Kemajuan ilmu pengetahuan dan perkembangan teknologi seharusnya membuka wawasan baru bagi guru bahwa masih banyak sumber belajar lain yang dapat dimanfaatkan untuk pembelajaran. Sehingga nantinya output yang dihasilkan sesuai dengan tujuan yang diharapkan.

Salah satu tujuan pendidikan mengarahkan manusia pada kehidupan yang lebih baik yang menyangkut derajat kemanusiaan sehingga mencapai tujuan hidupnya sesuai dengan asal kejadiannya. Sedangkan tujuan pendidikan nasional dalam Undang-undang Nomor 20 Tahun 2003 yaitu mengembangkan kemampuan dan membentuk watak serta peradaban bangsa yang bermartabat dalam rangka mencerdaskan kehidupan bangsa, bertujuan untuk berkembangnya potensi agar menjadi manusia yang beriman, dan bertakwa kepada Tuhan Yang Maha Esa, berakhlak mulia, sehat, berilmu, cakap, kreatif, mandiri, dan menjadi warga negara yang demokratis serta bertanggung jawab1.

Di samping itu, pendidikan kita saat ini masih belum sepenuhnya sesuai yang diharapkan, karena masih banyak ditemukan kompetensi yang dimiliki seorang guru masih rendah. Sehingga menghasilkan lulusan yang tidak kompeten. Salah satu faktor yang mengakibatkan rendahnya guru yaitu rendahnya kompetensi profesionalisme. Penguasaan guru terhadap materi, metode pembelajaran masih berada di bawah satandar ${ }^{2}$. Oleh karena itu, tugas guru yang pertama adalah merencanakan pembelajaran. Perencanaan harus dibuat sebaik mungkin karena perencanaan yang baik akan membawa hasil yang baik pula. ${ }^{3}$

Mutu pembelajaran merupakan hal pokok yang harus dibenahi secara terus-menerus dalam rangka peningkatan mutu pendidikan. Dalam hal ini guru menjadi titik fokusnya. Sebab guru

1 Kompri, Manajemen Pendidikan : Komponen-Komponen Elementer Kemajuan Sekolah, (Yogyakarta: Ar-Ruzz Media, 2015), 19.

2 Moh. Uzer Usman, Menjadi Guru Profesional, (Bandung: PT Remaja Rosdakarya, 2004), 02.

3 Barnawi \& Mohammad Arifin, Kinerja Guru Profesional: Instrumen Pembinaan, peningkatan, \& Penilaian, (Jogjakarta: Ar-Ruzz Media, 2012), 15. 
termasuk orang yang terlibat langsung dalam proses pembelajaran. Di samping itu, untuk meningkatkan mutu pendidikan perlu ditunjang oleh fasilitas pembelajaran yang memadai dan guru yang profesional, karena pembelajaran merupakan kegiatan bertujuan. Peningkatan mutu berbasis sekolah dapat dilaksanakan dengan baik bilamana didukung oleh keberadaan guru yang produktif dalam melakukan berbagai pengembangan sesuai dengan kebutuhan sekolah ${ }^{4}$. Keberadaan guru memiliki andil yang sangat besar terhadap keberhasilan pembelajaran di sekolah. Guru sangat berperan dalam membantu perkembangan peserta didik untuk mewujudkan tujuan hidupnya secara optimal. Misalnya minat, bakat, kemampuan dan potensi-potensi yang dimiliki peserta didik tidak akan berkembang secara optimal tanpa bantuan guru ${ }^{5}$.

Agar pembelajaran mampu memberikan makna bagi peserta didik, guru perlu mengembangkan strategi, pendekatan dan metode pembelajaran yang mampu mengaitkan materi pelajaran dengan kehidupan peserta didik sehari-hari. Kualitas pembelajaran dilihat pada intensitas keterkaitan sistemik dan sinergis antara perilaku pembelajaran guru, perilaku dan dampak belajar peserta didik, materi, sumber belajar, dan iklim pembelajaran dalam menghasilkan proses dan hasil belajar yang optimal.

Oleh karena itu, peningkatan mutu pembelajaran menjadi penting dalam rangka menjawab berbagai tantangan terutama globalisasi, kemajuan ilmu pengetahuan, teknologi serta pergerakan tenaga ahli yang sangat masif. Persaingan antar bangsapun berlangsung sengit dan intensif sehingga menuntut lembaga pendidikan untuk mampu melahirkan output pendidikan yang berkualitas, memiliki keahlian dan kompetensi profesional yang siap menghadapi kompetisi global.

\section{Metode Penelitian}

Penelitian ini menggunakan pendekatan kualitatif. Pendekatan kualitatif merupakan proses penelitian yang menghasilkan data deskriptif berupa kata-kata tertulis atau lisan dari orang dan perilaku yang diamati. Karena pendekatan kualitatif cocok digunakan untuk memperoleh pemahaman

4 Ibrahim Bafadal, Peningkatan Profesionalisme Guru Sekolah Dasar: Dalam Rangka Manajemen Peningkatan Mutu Berbasis Sekolah, (Jakarta: PT Bumi Aksara, 2013), 104.

${ }^{5}$ E Mulyasa, Menjadi Guru Profesional: Menciptakan Pembelajaran yang Kreatif dan Menyenangkan, (Bandung: PT Remaja Rosdakarya, 2017), 35. 
mendalam tentang fenomena sosial yang kompleks ${ }^{6}$. Adapun lokasi dalam penelitian ini, peneliti laksanakan di MTsN Sumber Bungur Pamekasan.

Subjek dalam penelitian ini adalah kepala madrasah, wakil kepala madrasah dan para guru. Semua subjek ini diharapkan memberi data tentang peningkatan mutu pembelajaran berbasis aneka sumber. Metode yang digunakan dalam pengumpulan data yang digunakan dalam penelitian ini adalah pengamatan/observasi, wawancara dan dokumentasi ${ }^{7}$. Di mana peneliti terlibat langsung di lokasi penelitian selama penelitian berlangsung sehingga memperoleh data yang lengkap dan akurat.

Dalam pemilihan informan, peneliti menggunakan teknik purposif sampling (sampel bertujuan) dengan memilih informan yang paling mengetahui informasi dan masalahnya secara mendalam ${ }^{8}$. Sample bertujuan tersebut diambil berdasarkan beberapa pertimbangan (disebabkan keterbatasan waktu, tenaga dan biaya) sehingga tidak bisa mengambil sample yang lebih luas.

Kemudian untuk memperoleh informasi yang akurat, maka dalam pengumpulan data melalui wawancara dan observasi, penelit menggunakan snowball sampling (bola salju), yaitu teknik pengambilan sumber data yang pada awalnya jumlahnya sedikit, lama-lama menjadi besar. Besar dalam artian informasi bertambah9. Hal ini dilakukan karena dari jumlah sumber data yang sedikit tersebut belum memberikan data yang memuaskan, maka mencari orang lain lagi yang dapat dijadikan sebagai sumber data.

\footnotetext{
6 Masykuri Bakri, Metode Penelitian Kualitatif Tinjauan Teoritis dan Praktis, (Surabaya: Visipress Media, 2013), 12.

${ }^{7}$ Sugiyono, Metode Penelitian Kuantitatif, Kualitatif dan R\&D, (Bandung: Alfabeta. 2014), 227.

8 Masykuri Bakri, Metode Penelitian Kualitatif Tinjauan Teoritis dan Praktis, (Surabaya: Visipress Media, 2013), 124.

9 Sugiyono, Memahami Penelitian Kualitatif, (Bandung: CV Alfabeta, 2014), 53.
} 
Analisis data yang digunakan dalam penelitian ini menggunakan model analisis data interaktif. ${ }^{10}$ Sebagaimana pada gambar di bawah.

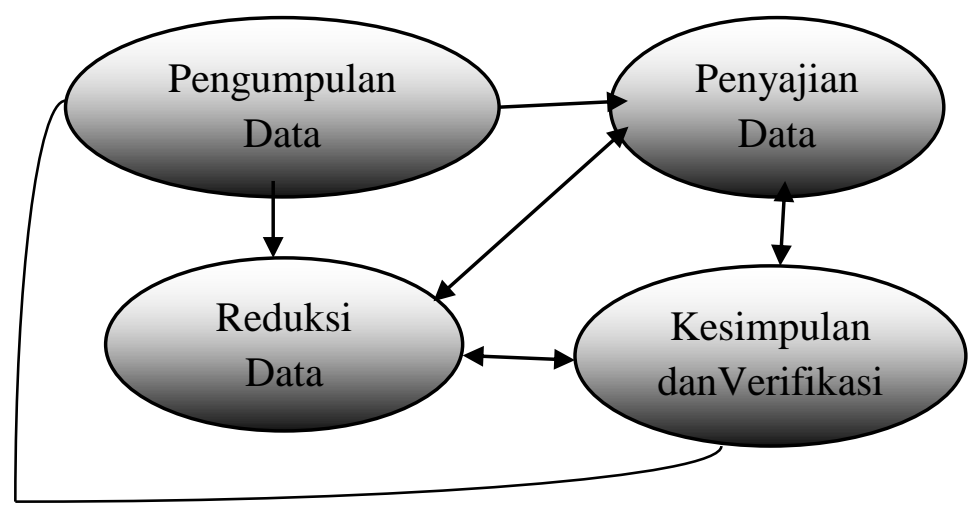

Gambar 1: Model Analisis Data Interaktif

\section{Mutu Pembelajaran}

Secara klasik, pengertian mutu (quality) menunjukkan sifat yang menggambarkan derajat baiknya suatu barang atau jasa yang diproduksi oleh suatu lembaga dengan kriteria tertentu. Sallis mendefinisikan mutu ke dalam dua perspektif, yaitu absolut dan relatif. Mutu absolut adalah mencerminkan tingginya penilaian harga barang atau jasa dan tinggi standar atau tingginya kualitas penilaian berdasarkan penilaian lembaga yang memproduksi barang tersebut. Sedangkan mutu relatif adalah mencerminkan tingginya penilaian harga barang atau jasa dan tingginya standar atau tingginya kualitas penilaian berdasarkan penilaian konsumen yang memanfaatkan barang atau jasa tersebut ${ }^{11}$.

Mutu adalah kemampuan (ability) yang dimiliki suatu produk atau jasa (services) yang dapat memenuhi kebutuhan atau harapan, kepuasan pelanggan (customers) yang dalam dunia pendidikan dibagi menjadi dua, yaitu internal customer dan eksternal. Internal customer yaitu peserta didik sebagai pelajar (learner) dan eksternal customer yaitu masyarakat ${ }^{12}$. Dalam konteks pendidikan mutu berkaitan dengan upaya memberikan pelayanan yang paripurna

10 Matthew B. Miles dan A. Michael Huberman, Analisi Data Kualitatif, Buku Sumber Tentang Metode-metode Baru, (Jakarta: UI-Press, 2002), 16.

11 Ridwan Abdullah Sani, Isda Pramuniati dan Anies Mucktiany, Penjaminan Mutu Sekolah, (Jakarta: Bumi Aksara, 2015), 3.

12 Nanang Fattah, Sistem Penjaminan Mutu Pendidikan, (Bandung: Remaja Rosdakarya, 2012), 2. 
dan memuaskan bagai para pemakai jasa pendidikan. Di samping itu, berkaitan juga dengan bagaimana input peserta didik, proses penyelenggaraan pendidikan dengan fokus layanan peserta didik, sampai bagaimana output lulusan yang dihasilkan.

Sagala menyatakan, bahwa mutu pendidikan adalah gambaran dan karakteristik menyeluruh jasa pelayanan pendidikan secara internal maupun eksternal yang menunjukkan kemampuannya, memuaskan kebutuhan yang diharapkan, atau yang tersirat mencakup input, proses, dan ouput pendidikan ${ }^{13}$. Dengan demikian, mutu berkaitan dengan kepuasan seseorang terhadap jasa yang dihasilkan oleh suatu instansi atau pendidikan. Karena itu, lembaga pendidikan harus selalu memperbaiki ouput lulusannya sebagaimana diharapkan.

Peningkatan mutu sekolah merupakan suatu proses yang sistematis yang terus menerus meningkatkan kualitas belajar mengajar dan faktor-faktor yang berkaitan dengannya dengan tujuan agar menjadi target sekolah dapat dicapai dengan lebih efektif dan efesien ${ }^{14}$. Mutu pendidikan harus ada kesesuaian antara kebutuhan pihak-pihak yang berkepentingan (stakeholders) dengan layanan yang diberikan oleh pengelola pendidikan. Kerangka filosofi pendidikan dalam pengembangan sekolah bermutu adalah kesesuaian input, proses, dan hasil sekolah dengan kebutuhan pemangku kepentingan ${ }^{15}$.

Dalam kacamata pemerintah, sekolah yang bermutu harus memenuhi Standar Nasional Pendidikan (SNP) berikut, yaitu (1) lulusan yang cerdas komprehensif; (2) kurikulum yang dinamis sesuai kebutuhan zaman; (3) proses pembelajaran yang berorientasi pada peserta didik dan mengembangkan kreativitasnya; (4) proses pembelajaran dilengkapi dengan sistem penilaian dan evaluasi pendidikan yang handal, sahih, dan memenuhi prinsip-prinsip penilaian; (5) guru dan tenaga kependidikan yang profesional, berpengalaman dan dapat menjadi teladan; (6) sarana dan prasarana yang digunakan lengkap dan sesuai dengan kearifan lokal; (7) sistem manajemen yang akurat dan handal; (8) pembiayaan pendidikan yang efektif dan efesien ${ }^{16}$.

13 Muhammad Fathurrohman dan Sulistyorini. Implementasi Manajemen Peningkatan Mutu Pendidikan Islam, (Yogyakarta: Teras, 2012), 45-46.

${ }^{14}$ Zamroni, Meningkatkan Mutu Sekolah, (Jakarta: PSAP Muhamadiyah, 2007), 2.

15 Ridwan Abdullah Sani, Isda Pramuniati dan Anies Mucktiany, Penjaminan Mutu Sekolah, (Jakarta: Bumi Aksara, 2015), 6.

16 Ibid, 3. 
Komponen kriteria pendidikan yang bermutu, antara lain: (1) materi pelajaran dirasakan manfaatnya oleh peserta didik baik dirasakan langsung maupun dikemudian, memberi wawasan yang bersifat meningkat secara terus menerus, memberi pengalaman berharga, menumbuhkan semangat, motivasi dan kreativitas berpikir, dan mampu mengubah sikap, pemikiran, dan perilaku; (2) perencanaan pendidikan yang baik tidak hanya untuk menciptakan dan mempersiapkan masa depan peserta didik, tapi juga untuk membekali mereka ketika menghadap Allah; dan (3) tata kelola pendidikan yang baik adalah sistem tata kelola yang bersifat komprehensif, saling terikat, dan berkesinambungan antar komponen ${ }^{17}$.

\section{Pembelajaran Berbasis Aneka Sumber Belajar}

Pembelajaran berbasis aneka sumber (resource-based learning) adalah bentuk belajar yang langsung menghadapkan peserta didik dengan suatu atau sejumlah sumber belajar secara individual atau kelompok yang dapat dilaksanakan di dalam kelas, laboratorium, perpustakaan, dalam "sumber belajar" yang khusus atau bahkan di luar sekolah ${ }^{18}$. Pembelajaran ini tidak meniadakan peranan guru. Guru terlibat dalam setiap langkah proses belajar, dari perencanaan, penentuan, dan mengumpulkan sumber-sumber informasi, memberi motivasi, memberi bantuan dan memperbaiki kesalahan $^{19}$.

Dalam pelaksanaan pembelajaran ini, guru perlu memperhatikan hal-hal berikut, yaitu (1) tujuan pembelajaran. Dalam hal ini, guru harus merumuskan tujuan pembelajaran dengan jelas apa yang ingin dicapai dari pelajaran; (2) memilih metode. Artinya, apabila topik yang dihadapi itu luas, seperti dalam pengajaran unit, maka berbagai ragam metode yang perlu digunakan guru; (3) koleksi dan penyediaan bahan. Dalam hal ini, guru harus memperhatikan bahan dan alat yang dimiliki oleh sekolah. Di samping itu, sumber-sumber belajar lain di luar sekolah perlu diselidiki oleh guru agar dapat dimanfaatkan ketika diperlukan; dan (4) penyediaan tempat. Dalam kegiatan pembelajaran ini memerlukan ruang tertentu, seperti ruang kelas, perpustakaan, laboratorium, dan lingkungan ${ }^{20}$.

17 Dedy Mulyasana, Pendidikan Bermutu dan Berdaya Saing, (Bandung: PT Remaja Rosdakarya, 2015), 120.

18 S. Nasution, Berbagai Pendekatan dalam Proses Belajar dan Mengajar, (Jakarta: PT Bumi Aksara, 2013), 18.

19 Ibid, 28.

20 Ibid, 30-31. 
Ciri-ciri pembelajaran berbasis aneka sumber memanfaatkan segala sumber sebagai sumber informasi bagi pelajaran termasuk alat-alat audio visual dan memberi kesempatan untuk merencanakan kegiatan belajar dengan mempertimbangkan sumber-sumber yang tersedia; (2) memberi pengertian pada peserta didik tentang luas dan aneka ragamnya sumber-sumber informasi yang dapat dimanfaatkan untuk belajar; (3) mengganti pasivitas peserta didik dalam belajar tradisional dengan belajar aktif didorong oleh minat dan keterlibatan diri dalam pembelajaran; (4) berusaha meningkatkan motivasi belajar dengan menyajikan berbagai kemungkinan tentang bahan pelajaran, metode kerja dan medium komunikasi; dan (5) lebih fleksibel dalam penggunaan waktu dan ruang belajar. Artinya dalam pembelajran ini peserta didik tidkdiharuskan belajar bersama dalam ruang yang sama pada waktu yang sama ${ }^{21}$.

\section{Jenis-jenis Sumber Belajar}

Sumber belajar adalah segala sesuatu yang ada di sekitar lingkungan kegiatan belajar yang secara fungsional dapat digunakan untuk membantu optimalisasi hasil belajar. Optimalisasi hasil belajar di sini tidak hanya dapat dilihat dari hasil belajar (output), melainkan juga dari proses berupa interaksi peserta didik dengan berbagai sumber belajar yang dapat merangsang peserta didik untuk belajar dan mempercepat pemahaman dan penguasaan pengetahuan 22 .

Dalam Assosiasi Teknologi Komunikasi Pendidikan (AECT), sumber belajar meliputi: (1) pesan (message) adalah informasi pembelajaran yang disampaikan kepada peserta didik baik berupa ide, fakta, ajaran, nilai, dan data; (2) orang (people) adalah menusia yang berperan sebagai pencari, penyimpan, pengolah, dan penyaji pesan; (3) bahan (materials) merupakan perangkat lunak (software) yang mengandung pesan-pesan pembelajaran yang biasanya disajikan melalui peralatan tertentu maupun oleh dirinya sendiri; (4) alat (devices) adalah merupakan perangkat (hadware) yang digunakan untuk menyajikan pesan yang tersimpan dalam bahan, misalnya $\mathrm{OHP}$, proyektor slide, tape recorder, video/CD player, komputer, proyektor film, dan lain-lain; (5) teknik (technique) adalah prosedur atau langkah-langkah tertentu yang

21 Ibid, 26-28.

22 Wina Sanjaya, Perencanaan dan Desain Sistem Pembelajaran, (Jakarta: Kencana Prenada Media Group, 2008), 288. 
disiapkan dalam menggunakan bahan, alat, lingkungan dan orang untuk menyampaikan pesan; dan (6) lingkungan (setting) adalah situasi di sekitar terjadinya proses pembelajaran peserta didik menerima pesan pembelajaran ${ }^{23}$.

Ditinjau dari tipe atau asal-usulnya, sumber belajar dibedakan menjadi dua jenis, yaitu (1) Sumber belajar yang dirancang (learning resources by design), yaitu sumber belajar yang secara khusus atau sengaja dirancang atau dikembangkan untuk mencapai tujuan pembelajaran tertentu. Misalnya, buku pelajaran, modul, program VCD pembelajaran, program audio pembelajaran, transparansi, CAI (Computer Asisted Intruction), programmed intruction dan lain-lain; dan (2) sumber belajar yang sudah tersedia dan tinggal dimanfaatkan (learning resources by utilization), yaitu sumber belajar yang secara tidak khusus dirancang atau dikembangkan untuk keperluan pembelajaran, tetapi dapat dipilih dan dimanfaatkan untuk keperluan pembelajaran. Contoh, surat kabar, siaran televisi, pasar, sawah, waduk, pabrik, museum, kebun binatang, terminal, pejabat pemerintah, tenaga ahli, pemuka agama, olah ragawan, dan lain-lain ${ }^{24}$.

Sumber belajar ini akan menjadi bermakna bagi peserta didik maupun guru apabila sumber belajar diorganisir melalui satu rancangan yang memungkinkan seseorang memanfaatkannya sebagai sumber belajar dalam proses pembelajaran. Jika tidak dimanfaatkan maka sumber belajar tersebut tidak akan berarti apa-apa ${ }^{25}$. Oleh karena itu, guru perlu merancangnya, mendesain, mengorganisasikan dan memanfaatkannya sebaik mungkin agar memudahkan peserta didik dalam proses pembelajaran.

\section{Hasil dan Pembahasan \\ Peningkatan Mutu Pembelajaran}

Pada tahun 1968, KH. Ahmad Madani mendirikan Madrasah Mu'allimin, dua tahun kemudiaan pada tahun 1970 berubah menjadi Madrasah Tsanawiyah Agama Islam Negeri (MTsAIN). Kemudian pada tahun 1972 sampai sekarang, lembaga pendidikan ini berubah menjadi Madrasah Tsanawiyah Negeri yang secara otomatis pengelolaannya berada di bawah naungan Pemerintah (Kementerian Agama). Pada tahun 1990 melalui piagam yang ditanda tangangi oleh Menteri Agama, dan serah terimanya di

\footnotetext{
23 Bambang Warsita, Teknologi Pembelajaran: Landasan \& Aplikasinya, (Jakarta: Rineka Cipta, 2008), 210.

${ }^{24}$ Ibid, 212.

25 Abdul Majid, Perencanaan Pembelajaran: Mengembangkan Standar Kompetensi Guru, (Bandung: PT Remaja Rosdakarya, 2012), 171.
} 
Yogyakarta lembaga pendidikan ini menjadi Madrasah model. Saya menyerahkan segala bentuk pengelolaannya kepada pemerintah karena mereka memang ahli di bidangnya selain itu dengan pertimbangan kesejahteraan guru. ${ }^{26}$

Berkaitan dengan pencapaian tujuan pendidikan nasional dan Standar Kompetensi Lulusan yang telah ditetapkan, maka Kepala Madrasah dan civitas madarasah serta dengan komite madrasah menetapkan sasaran program/kegiatan pokok strategis, baik untuk jangka pendek, menengah dan jangka panjang. Sasaran program dimaksudkan untuk mewujudkan visi dan misi MTsN Sumber Bungur Pamekasan. Sasaran program tersebut selanjutnya ditindaklanjuti dengan strategi pelaksanaan yang wajib dilaksanakan oleh warga madrasah. Misalnya melengkapi fasilitas atau sumber belajar, mengadakan pembinaan terhadap peserta didik, guru dan karyawan secara berkelanjutan, membimbing dan menyelenggarakan pembelajaran yang integratif berwawasan lingkungan.

Berkaitan dengan fasilitas atau sumber belajar yang menjadi prioritas adalah: pertama, berupa bahan. Misalnya berbagai buku ajar, referensi, dan modul. Penyediaan buku, atau referensi yang memadai memudahkan guru dan peserta didik dalam proses pembelajaran. Sehingga di dalam pembelajaran guru tidak hanya menggunakan satu buku sebagai bahan ajar, melainkan juga menggunakan sumber lain yang relevan serta membantu memudahkan proses belajar mengajar di dalam kelas. Dengan penggunaan sumber yang beraneka ragam tersebut, maka pemahaman peserta didik lebih luas. Apalagi perkembangan ilmu yang begitu cepat, jika hanya mengandalkan satu sumber saja dalam pembelajaran maka pengetahuan kita akan menjadi usang.

Penggunaan media atau sumber belajar yang bervariasi dalam pembelajaran tersebut dapat membantu memperjelas sebagian dan keseluruhan materi pelajaran yang sulit dijelaskan secara verbal atau kata-kata. Di samping itu, penggunaan media dalam pembelajaran pada materi tertentu memang penting. Sebab keberhasilan pembelajaran juga ditentukan oleh apa yang dilihat dan apa yang dingar.

Kedua, berupa alat pembelajaran. Misalnya, proyektor, LCD, dan komputer. Penggunaan proyektor dan LCD dalam proses belajar mengajar dapat memudahkan guru dalam menyajikan informasi dan bahan secara lebih konkrit. Sehingga peserta didik

${ }^{26}$ Moh. Wardi, "Modernisasi Mu'allimin" Ta'limuna Jurnal Pendidikan Islam, Vol. 7 No. 1 Maret 2014, 96. 
dapat menangkap peristiwa-peristiwa yang berkaitan dengan materi pelajaran secara langsung, menambah gairah, motivasi belajar serta pembelajaran lebih efektif dan optimal karena mereka tidak hanya mendengarkan saja. Di samping itu, proses pembelajaran lebih menarik dan tidak membosankan.

Pemanfaatan proyektor dan LCD dalam kegitan pembelajaran juga dapat mengurangi beban guru dalam menyajikan informasi, sehingga dapat lebih banyak membina serta dapat menyajikan informasi atau bahan sebagaimana aslinya. Tersedianya sumber belajar yang memadai, dapat membantu mengoptimalkan hasil pembelajaran dan memungkinkan terjadinya interaksi peserta didik dengan berbagai macam sumber belajar tersebut, sehingga dapat merangsang peserta didik untuk belajar dan mempercepat pemahaman.

Ketiga, pemanfaatan lingkungan. Misalnya, halaman sekolah, perpustakaan, laboratorium, aula, dan lain-lain. Pemanfaatan perpustakaan ini sebagai sumber belajar sangat membantu memudahkan peserta didik untuk belajar secara mandiri. Proses belajar mengajar yang dilakukan di perpustakaan ini bisa meningkatkan partisipasi peserta didik secara lebih aktif. Karena keberadaan perpustakaan di sekolah bukan hanya untuk menyimpan bahan-bahan pustaka, melainkan juga membantu peserta didik dan guru dalam melaksanakan kegiatan belajar mengajar. Perpustakaan merupakan komponen penting yang dapat menunjang kegiatan belajar mengajar serta membantu memudahkan peserta didik untuk belajar secara mandiri, dan mengurangi kebosanan. Keberadaan perpustakaan menjadi salah satu sumber belajar yang tidak bisah dipisahkan dari lembaga pendidikan untuk memperkaya, mendukung, memberikan kekuatan dan mengupayakan penerapan pendidikan yang memenuhi kebutuhan peserta didik serta mendorong dan mengoptimalkan potensi mereka.

Pemanfaatan laboratorium dalam pembelajaran apabila materi pelajaran mengharuskan praktik. Terutama kurikulum 2013, K4 mengharuskan peserta didik melakukan praktik, maka guru yang bersangkutan harus merencanakan dan mempersiapkan peserta didik untuk dibawa ke laboratorium. Di samping itu, di madrasah ini dalam pembelajaran juga memanfaatkan halaman sekolah sebagai tempat belajar, yang dikenal dengan istilah pembelajaran yang integratif berwawasan lingkungan.

Keempat, mengadakan pembinaan terhadap guru, karyawan dan peserta didik secara berkelanjutan. Sebenarnya banyak strategi yang dilakukan sekolah dalam rangka membina 
kompetensi para guru, seperti diadakan pelatihan, diklat dan workshop kependidikan dilingkungan sekolah dan bahkan kadang dikirim ke luar sekolah. Tujuannya agar wawasan dan keterampilan para guru dalam mengajar semakin luas. Di samping itu, karena mereka yang terlibat langsung dalam proses pembelajaran sekaligus penentu keberhasilan pembelajaran.

Bahkan di madrasah ini terdapat tiga program kelas dalam rangka meningkatkan kualitas pembelajaran. Pertama, kelas layanan program sistem kredit semester (SKS) 4 Semester (2 Tahun) merupakan kelas program baru yang dimiliki oleh MTsN Sumber Bungur. Kelas layanan ini merupakan bagian dari tuntutan perkembangan pendidikan yang semakin membutuhkan inovasi. Kelas ini diprioritaskan bagi peserta didik yang memiliki kelebihan dalam kemampuan menyerap materi pembelajaran, kelebihan kecepatan dalam belajar, sehingga harapannya peserta didik kelas ini mampu menyelesaikan studi dalam rentang waktu 2 (dua) tahun.

Kedua, dilaksanakan kelas layanan program sistem kredit semester (SKS) 5 Semester (2 Tahun). Kelas layanan ini merupakan bagian dari tuntutan perkembangan pendidikan yang semakin membutuhkan inovasi. Kelas layanan ini diprioritaskan bagi peserta didik yang memiliki kelebihan dalam kemampuan menyerap materi pembelajaran, kelebihan kecepatan dalam belajar, sehingga harapannya peserta didik kelas layanan program ini mampu menyelesaikan studi dalam rentang waktu 2 (dua) tahun. Target yang diharapkan dari kelas ini adalah agar peserta didik memiliki kemampuan sesuai bakat dan minatnya serta mampu mempertahankan dan meningkatkan tradisi madrasah meraih prestasi ditingkat internasional sehingga memiliki nilai guna dalam penerapannya di lingkungan masyarakat.

Ketiga, kelas layanan inklusi program 6 (Enam) Semester yang menggunakan kurikulum madrasah 2013 yang berdiferensiasi dan eskalasi dengan menggunakan bahasa inggris dan bahasa arab sebagai pengantar dalam pembelajaran, dengan masa tempuh studi 3 (tiga) tahun. Target yang ingin dicapai dari beberapa program kelas kelas ini agar terbentuk peserta didik berkaraktrer Islami yang mampu berbahasa Inggris dan bahasa Arab secara aktif dan pasif untuk menghadapi perkembangan internasional.

\section{Perencanaan Pembelajaran}


Hasil penelitian menunjukkan bahwa perencanaan pembelajaran di MTsN Sumber Bungur Pamekasan dilakukan oleh guru dan tenaga kependidikan serta disusun sesuai dengan petunjuk dan pengembangan silabus dengan berpedoman pada standar kompetensi (SK) dan kompetensi dasar (KD) serta merumuskan indikator, dan menyusun RPP. Keberadaan silabus dan RPP menjadi acuan dalam memuat materi dan sumber atau alat media yang akan digunakan, maka dari itu guru dituntut untuk peka terhadap media dan alat yang akan dimuat dalam perencaan tersebut. Namun dalam perencanaan tersebut guru tetap mengacu pada kurikulum khususnya silabus sebagai acuan utama dalam menyusun perencanaan pembelajaran dan disesuaikan dengan kondisi sekolah.

Dalam perencanaan pembelajaran tersebut guru menentukan materi ajar, penggunaan media, penggunaan pendekatan, metode dan penilaian. Di samping itu, perencanaan pembelajaran di madrasah ini disusun dengan mempertimbangkan relevansi materi pelajaran dengan karakteristik peserta didik untuk mebentuk perilaku pada aspek pengetahuan, sikap dan keterampilan. Penentuan pendekatan dan metode pembelajaran sangat penting. Sebab sebaik apapun materi dan tujuan pembelajarannya, tanpa dibarengi dengan penggunaan metode yang tepat dan sesuai maka, tujuan pembelajaran tersebut tidak akan berguna apa-apa. Oleh karena itu, diperlukan keterampilan guru dalam proses pembelajaran agar mudah diterima oleh peserta didik dengan optimal atau seluruh materi pelajaran dapat dipahami dengan baik oleh peserta didik.

\section{Dampak Peningkatan Mutu Pembelajaran}

Banyak prestasi yang diraih atau diukir oleh peserta didik MTsN Sumber Bungur Pamekasan baik tingkat kabupaten, Madura, Jawa Timu, Nasional dan bahkan Internasional terutama pada tahun 2016-2017. Hal tersebut menjadi suatu kebanggaan bagi guru dan tenaga kependidikan di lingkungan madrasah karena telah bisa mengantarkan peserta didiknya berkompetisi dibeberapa tingkat. Prestasi tersebut tidak banyak diraih oleh lembaga sederajat yang berada di bawah naungan Kementerian Agama Kabupaten Pamekasan.

Perkembangan MTsN Sumber Bungur Pamekasan banyak mengalami kemajuan dan peningkatan, baik dari bertambahnya peserta didik, lengkapnya fasilitas, maupun tambahan staf pengajar yang profesional dibidangnya. Di samping itu, terdapat beberapa peserta didik dari luar Pamekasan bahkan dari luar Madura yang 
memang sengaja datang ke MTsN Sumber Bungur Pamekasan untuk menimba ilmu. Di antaranya mereka ada yang berasal dari Bali, Bandung, Sidoarjo, Surabaya, dan beberapa kota lainnya.

Meskipun letaknya jauh dari kota Pamekasan, yaitu sekitar $22 \mathrm{Km}$, akan tetapi eksistensi MTsN Sumber Bungur Pamekasan tetap menjadi salah satu lembaga pendidikan Islam yang terpilih sebagai madrasah percontohan. Sebagai salah satu bukti konkritnya adalah bahwa prestasi yang telah dihasilkan dan kemampuannya berkompetisi dalam keilmuan yang bersifat umum dan agama dengan sekolah dan madrasah lain, terutama sekolah dan madrasah favorit di Kota Pamekasan.

Tabel Prestasi MTsN Sumber Bungur Pamekasan Tahun 2016-2017

\begin{tabular}{|c|c|l|c|}
\hline NO & $\begin{array}{c}\text { PRESTASI } \\
\text { JUARA }\end{array}$ & \multicolumn{1}{|c|}{ KEGIATAN } & TINGKAT \\
\hline \hline 1 & $\begin{array}{c}\text { Bronze Award } \\
\text { (Perunggu) }\end{array}$ & $\begin{array}{l}\text { Singapore and Asian } \\
\text { Schools Math Olympiade } \\
\text { (SASM0) Singapore }\end{array}$ & Internasional \\
\hline 2 & $\begin{array}{c}\text { Distincion } \\
\text { (Silver Award) }\end{array}$ & $\begin{array}{l}\text { International } \\
\text { Competitions and } \\
\text { Assessments For Schools } \\
\text { (ICAS) Australia }\end{array}$ & Internasional \\
\hline 3 & $\begin{array}{c}\text { Credit (Bronze } \\
\text { Award) }\end{array}$ & $\begin{array}{l}\text { International } \\
\text { Competitions and } \\
\text { Assessments For Schools } \\
\text { (ICAS) Australia }\end{array}$ & Internasional \\
\hline 4 & Rangking 9 & $\begin{array}{l}\text { Lomba mading 3D } \\
\text { Tingkat Jawa Timur }\end{array}$ & Jawa Timur \\
\hline 5 & Juara I & $\begin{array}{l}\text { Matematika New Era } \\
\text { Mencari Bintang }\end{array}$ & Madura \\
\hline 6 & Juara II & $\begin{array}{l}\text { B. Inggris New Era } \\
\text { Mencari Bintang }\end{array}$ & Madura \\
\hline 7 & Juara 1 & Adiwayata Award & $\begin{array}{c}\text { Kabupaten } \\
\text { Pamekasan }\end{array}$ \\
\hline 8 & Medali Emas & $\begin{array}{l}\text { Lari 1500 m Kab. } \\
\text { Pamekasan }\end{array}$ & Pamekasan \\
\hline 9 & Juara I & PSF Kategori Kemenag & Pamekasan \\
\hline 10 & Juara I & PSF Kategori SMP/MTs & Pamekasan \\
\hline
\end{tabular}




\section{Kesimpulan}

Dalam upaya peningkatan mutu pembelajaran di MTsN Sumber Bungur Pamekasan dilakukan beberapa tahap. Pertama, dilakukan pembinaan guru karena guru termasuk orang yang terlibat langsung serta menjadi ujung tombak dalam menentukan keberhasilan proses pembelajaran. Kedua, penyediaan fasilitas pembelajaran yang memadai, seperti bahan dan alat pembelajaran. Dengan dilengkapinya fasilitas pembelajaran tersebut semua kebutuhan guru dan peserta didik dapat terpenuhi. Sehingga dalam proses pembelajarannya memudahkan bagi guru dan peserta didik. Ketiga, proses pembelajaran tidak hanya dilakukan di kelas saja, akan tetapi juga dilakukan di luar kelas, seperti di perpustakaan, sehingga peserta didik dapat belajar secara mandiri.

Dalam upaya meningkatkan mutu pembelajaran, di MTsN Sumber Bungur Pamekasan dalam melakukan perencanaan pembelajaran selalu mengacu pada kurikulum khususnya silabus sebagai acuan utama dalam menyusun perencanaan pembelajaran dan disesuaikan dengan kondisi sekolah. Di dalam perencanaan tersebut memuat beberapa komponen penting, yaitu menentukan materi ajar, media, pendekatan, metode yang dan bentuk penilaian yang akan dilakukan. Penentuan komponen tersebut dalam rencana pembelajaran memang penting sebab akan menentukan keberhasilan pembelajaran.

Tak sedikit prestasi yang telah diukir oleh peserta didik MTsN Sumber Bungur Pamekasan khususnya pada tahun 2016 baik tingkat Kabupaten, Madura, Jawa Timur, Nasional dan bahkan Internasional. Hal tersebut tidak lepas dari peran Kepala Madrasah dan civitas madarasah serta dengan komite madrasah menetapkan sasaran program/kegiatan tersebut. Khususnya kemampuan dan keterampilan guru dalam melaksanakan pembelajaran.

\section{Daftar Pustaka}

Bafadal, Ibrahim. Peningkatan Profesionalisme Guru Sekolah Dasar Dalam Kerangka Manajemen Peningkatan Mutu Berbasis Sekolah, (Jakarta: Bumi Aksara, 2013)

Bakri, Masykuri. Metode Penelitian Kualitatif Tinjauan Teoritis dan Praktis, (Surabaya: Visipress Media, 2013)

Barnawi dan Muhammad Arifin. Kinerja Guru Prpfesional, (Jogjakarta: Ar-Ruzz Media, 2012) 
Fattah, Nanang. Sistem Penjaminan Mutu Pendidikan, (Bandung: PT Remaja Rosdakarya, 2012)

Kompri, Manajemen Pendidikan : Komponen-Komponen Elementer Kemajuan Sekolah, (Yogyakarta: Ar-Ruzz Media, 2015)

Majid, Abdul. Perencanaan Pembelajaran: Mengembangkan Standar Kompetensi Guru, (Bandung: PT Remaja Rosdakarya, 2012)

Matthew B. Miles dan A. Michael Huberman. Analisi Data Kualitatif, Buku Sumber Tentang Metode-metode Baru, (Jakarta: UIPress, 2002)

Muhammad Fathurrohman dan Sulistyorini. Implementasi Manajemen Peningkatan Mutu Pendidikan Islam, (Yogyakarta: Teras, 2012)

Mulyasa, E. Menjadi Guru Profesional: Menciptakan Pembelajaran yang Kreatif dan Menyenangkan, (Bandung: PT Remaja Rosdakarya, 2017)

Mulyasana, Dedy. Pendidikan Bermutu dan Berdaya Saing, (Bandung: PT Remaja Rosdakarya, 2015)

Nasution, S. Berbagai Pendekatan dalam Proses Belajar dan Mengajar, (Jakarta: PT Bumi Aksara, 2013)

Ridwan Abdullah Sani, Isda Pramuniati dan Anies Mucktiany. Penjaminan Mutu Sekolah, (Jakarta: Bumi Aksara, 2015)

Sanjaya, Wina. Perencanaan dan Desain Sistem Pembelajaran, (Jakarta: Kencana Prenada Media Group, 2008)

Sugiyono. Metode Penelitian Kuantitatif, Kualitatif dan R\&D, (Bandung: Alfabeta. 2014)

Sugiyono. Memahami Penelitian Kualitatif, (Bandung: CV Alfabeta, 2014)

Uzer Usman, Moh. Menjadi Guru Profesional, (Bandung: PT Remaja Rosdakarya, 2004)

Wardi, Moh. "Modernisasi Mu'allimin" Ta'limuna Jurnal Pendidikan Islam, Vol. 7 No. 1 Maret 2014.

Warsita, Bambang. Teknologi Pembelajaran: Landasan \& Aplikasinya, (Jakarta: Rineka Cipta, 2008)

Zamroni, Meningkatkan Mutu Sekolah, (Jakarta: PSAP Muhamadiyah, 2007) 